\title{
Oncolytic bluetongue viruses: promise, progress, and perspectives
}

\author{
Joseph K.-K. Li* \\ Department of Biology, Utah State University, Logan, UT, USA
}

\section{Edited by:}

Abraham L. Brass, Massachusetts General Hospital, USA

\section{Reviewed by:}

Manoj N. Krishnan, Duke-NUS Graduate Medical School, Singapore

Dahlene N. Fusco, Massachusetts

General Hospital, USA

${ }^{*}$ Correspondence:

Joseph K.-K. Li, Department of Biology, Utah State University, 5305 Old Main Hill, VSB 323, Logan, UT 84322-5305, USA.e-mail: joseph.li@usu.edu
Humans are sero-negative toward bluetongue viruses (BTVs) since BTVs do not infect normal human cells. Infection and selective degradation of several human cancer cell lines but not normal ones by five US BTV serotypes have been investigated. We determined the susceptibilities of many normal and human cancer cells to BTV infections and made comparative kinetic analyses of their cytopathic effects, survival rates, ultra-structural changes, cellular apoptosis and necrosis, cell cycle arrest, cytokine profiles, viral genome, mRNAs, and progeny titers. The wild-type US BTVs, without any genetic modifications, could preferentially infect and degrade several types of human cancer cells but not normal cells. Their selective and preferential BTV-degradation of human cancer cells is viral dose-dependent, leading to effective viral replication, and induced apoptosis. Xenograft tumors in mice were substantially reduced by a single intratumoral BTV injection in initial in vivo experiments. Thus, wild-type BTVs, without genetic modifications, have oncolytic potentials. They represent an attractive, next generation of oncolytic viral approach for potential human cancer therapy combined with current anti-cancer agents and irradiation.

Keywords: oncolytic bluetongue viruses, cancer treatment, selective cytotoxic effects, viratherapeutics
Parasites, fungi, bacteria, and viruses are the four major types of human pathogens causing many human diseases with cellular damages and continuous confrontations to our immune systems. Humans tend to dislike their existence. However, recent scientific findings indicated that especially with viruses, the infectious, and pathological outcomes can be converted to some beneficial potential for human health. The potential application of viruses to retard the growth of human cancers was initially introduced by Dock (1904) when he published a landmark article in the American Journal of Medical Science entitled "Influence of complicating diseases upon leukemia." He had observed and recorded that the white blood cell count of a patient with chronic myelogenous leukemia (CML) decreased dramatically during what was described as a flu-like illness. Thus, he "bravely" made the first suggestion to fellow physicians to use viral infection to treat tumors. The exciting idea of using viruses to destroy cancer cells led numerous medical treatment attempts for over five subsequent decades. However, using only wild-type viruses without genetic modifications such as selective genetic deletion of viral virulent domains or modification of viral genes critical for viral replication and the addition of immune enhancer genes have not been successful. Parallel to this innovative idea was the suggested use of "superbugs" called bacteriophages that kill bacteria but do not harm humans, to combat pathogenic bacteria that kill thousands of people globally each year (Hausler, 2006). The subsequent discovery of phage genetic conversion that might lead to production of either endotoxin and/ or exotoxin tempered the use of this medical "superbug" therapy (Singer, 1976) but this approach has begun to resurface in recent years. With the introduction and availability of penicillin to combat bacteria, both medical "superbug" therapy and uses of viral infection to treat and destroy different cancers were largely ignored in the twentieth century (Liu, 2006; Liu et al., 2007). Thus, a century of work on potential uses of oncolytic viruses to treat cancers has not been well accepted and this approach has not yet generated any significant breakthroughs to treat human cancers.

In 1998, Professor Patrick Lee and his associates at the University of Alberta, Calgary provided the first data and evidence that reovirus with a segmented double-stranded (ds) RNA genome could selectively destroy certain human cancer cells in vitro (Strong et al., 1998). This "proof-of-principle" demonstration was a novel breakthrough and has raised hope that reovirus specifically and other viruses (Kim et al., 2006) with oncolytic potentials can be killing machines against human cancers (Kikuchi et al., 1997; Rodgers et al., 1997; Liu, 2006; Holtz, 2007). Through intensive investigation and exploration, the oncolytic potentials of viruses have been discovered in six major viral families, reovirus type 3, papillomaviruses, herpesviruses, hepadnaviruses, flaviviruses, and retroviruses (Norman and Lee, 2005; Alain et al., 2006, 2007; Kim et al., 2006; Shen and Nemunaitis, 2006; Vidal et al., 2006; Burroughs et al., 2007; Qi et al., 2007; Cripe et al., 2009; Ou and Yen, 2010). Since all these, with the exception of reovirus, are also "human cancer viruses" and they cause more than a fourth of all human cancers, innovative methods incorporating recent advances (Wildner, 2003) in molecular biology and genomics/proteomics have been developed and/or modified in the last decade to reduce the pathology of these viruses and to direct and enhance their specific oncolytic activities against different cancer cells and tumors (Aghi and Martuza, 2005; Alain et al., 2006; Holtz, 2007; Ou and Yen, 2010). This generally involves deleting or modifying essential viral genes that restrict the replication of these viruses except in cancer cells. In recent years, combinatory approaches using RNA interference (RNAi) or the addition of transgenes, whose products target molecules that are over-expressed only or preferentially in cancer cells, have also been formulated with the uses of these oncolytic viruses. 
One potential next generation newcomer recently discovered in the oncolytic virus field is the bluetongue virus (BTV), the genomics, and proteomics of which we have worked with for the last 25 years (Kowalik and Li, 1987, 1989, 1991; Li et al., 1987, 1989; Kowalik et al., 1990a,b; Li and Yang, 1990, 1992; Hwang et al., 1992a,b, 1993, 1994; Yang and Li, 1992, 1993; Li and Hwang, 1992; Yang et al., 1992a,b; Huang et al., 1993, 1995; Hwang and Li, 1993; Hayama and Li, 1994; Wang et al., 1996; Huang and Li, 1997, 2000; Fillmore et al., 2002; Xiao et al., 2004; Hu et al., 2008). BTV belongs to the orbivirus (ring or circle in Greek) genus of the Reoviridae Family which also includes the reovirus. BTVs were initially isolated in several endemic episodes in Africa in late 1960s and early 1970s (Goltz, 1978; Erasmus, 1985; Gorman, 1990). Currently there are 24 different BTV serotypes worldwide. The viral genome of BTVs contains 10 ds-RNA fragments, each of which encodes for one viral structural or non-structural protein (Roy, 1989, 1992) except the S4 fragments that can encode for two non-structural proteins (Wu et al., 1992; Hyatt et al., 1993). BTV transmitted via the blood-feeding midges, Culicoides variipennis in North America and C. imicolain in Africa and the Middle East, is the causal agent of bluetongue disease (BD) in domestic cattle and wild ruminants, with virus-induced hemorrhagic fevers (HVFs), vasculitis, edema of the face, lips, muzzle, and ears, excessive salivation, hyperemia of the oral mucosa, and various necrosis and apoptosis of epithelial and mucosal surfaces (Goltz, 1978; Barratt-Boyes and MacLachlan, 1995; Huang and Li, 2000). Neurovirulence has also been detected with some recent BTV isolates (Waldvogel et al., 1987; Carr et al., 1994). With nasal mucopurulent discharges, the tongue becomes cyanotic, and thus, the name, BTV.

Bluetongue viruses (BTVs) are associated with BD in domestic cattle and wild ruminants with much interspecies variability (Goltz, 1978; Gibbs, 1983; Gibbs et al., 1983; Erasmus, 1985; Gorman, 1990), including fatality in sheep and progressive recovery in wild ruminants after BTV infection. Molecular biology efforts from our group (Kowalik and Li, 1987, 1989, 1991; Li et al., 1987, 1989; Kowalik et al., 1990a,b; Li and Yang, 1990, 1992; Hwang et al., 1992a,b, 1993, 1994; Yang and Li, 1992, 1993; Li and Hwang, 1992; Yang et al., 1992a,b; Huang et al., 1993, 1995; Hwang and Li, 1993; Hayama and Li, 1994; Wang et al., 1996; Huang and Li, 1997, 2000; Fillmore et al., 2002; Xiao et al., 2004; Hu et al., 2008) and other research groups such as Polly Roy (Purdy et al., 1984; Ghiasi et al., 1985; Lee and Roy, 1986, 1987; Fukusho et al., 1987, 1989; Yu et al., 1987, 1988; Roy et al., 1988, 1991, 1990a,b,c, 1992, 2009; Urakawa and Roy, 1988; Wang et al., 1988; Roy, 1989, 1992, 1996, 2003; French and Roy, 1990; French et al., 1990; Hirasawa and Roy, 1990; Marshall and Roy, 1990; Marshall et al., 1990; Oldfield et al., 1990, 1991; Roy and Gorman, 1990; Iwata et al., 1991; Loudon and Roy, 1991; Bremer et al., 1992; Chuma et al., 1992; Hewat et al., 1992a,b,c, 1994; LeBlois et al., 1992; Liu et al., 1992; Hyatt et al., 1993; Monastyrskaya et al., 1994; Tanaka and Roy, 1994; Zhao et al., 1994; Tanaka et al., 1995; Jones et al., 1996; Mikhailov et al., 1996; Yi et al., 1996; Basak et al., 1997; Stauber et al., 1997; Bansal et al., 1998; Martinez-Costas et al., 1998; Ramadevi and Roy, 1998; Ramadevi et al., 1998a,b; Hassan and Roy, 1999; Horscroft and Roy, 2000; Limn et al., 2000; Diebold et al., 2003; Mortola et al., 2004; Roy and Noad, 2006; Boyce and Roy, 2007; Marcato et al., 2007), Peter Mertens (Mertens et al., 1984, 1987, 1996; Mertens and Sangar,
1985; Wade-Evans et al., 1992; Pritchard et al., 1995; Ramadevi et al., 1998a; Gouet et al., 1999), Henk Huismans (Huismans, 1979, 1985; Huismans and Els, 1979; Van Dijk and Huismans, 1982; Huismans et al., 1987a,b,c; Hall et al., 1989; Huismans and Van Dijk, 1990; Nel et al., 1991; Uitenweerde et al., 1995), Van Djik (Van Dijk and Huismans, 1982, 1988; Hall et al., 1989; Van Dijk, 1993), Bryan Eaton (Eaton et al., 1987, 1988, 1990, 1991; Gould et al., 1988a; Eaton and Crameri, 1989; Hyatt et al., 1991, 1998; Martyn et al., 1991; Du Plessis et al., 1994; Murray and Eaton, 1996), Alan Gould (Gould and Pritchard, 1988; Gould et al., 1988a,b, 1994; Eaton et al., 1991; Hyatt et al., 1991; Martyn et al., 1991, 1994; Pritchard and Gould, 1995; Pritchard et al., 1995), B. Gorman (Cowley and Gorman, 1987, 1989, 1990; Gould et al., 1988a), William Wilson (Wilson, 1991; Pritchard et al., 1995; Xu et al., 1997), J. Mecham (Sundin and Mecham, 1989; Mecham and Jochim, 1990; Xu et al., 1997), B. Osborn (Barber et al., 1985; Stott et al., 1985; Oberst et al., 1987; Waldvogel et al., 1987; Unger et al., 1988; de Mattos et al., 1991; He et al., 1991; Carr et al., 1994; Odeon et al., 1999), N. J. MacLachlan (Whetter et al., 1990; Rossitto and MacLachlan, 1992; Barratt-Boyes and MacLachlan, 1995; DeMaula et al., 2000, 2001), M. J. Grubman (Campbell and Grubman, 1985; Devaney et al., 1988; Grubman and Samal, 1989; Grubman et al., 1990; Lewis and Grubman, 1990), M. H. Jeggo (Jeggo and Wardley, 1982a,b, 1985; Jeggo et al., 1983), L. F. Wang (Wang et al., 1988, 1989, 1994, 1996; He et al., 1991; Nagesha et al., 2001), A. M. Wade-Evans (WadeEvans, 1990a,b, 1992; Wade-Evans et al., 1992, 1996; Pritchard et al., 1995), and others (Shipham, 1979; Moss et al., 1990; Dunn et al., 1991; Cowley, 1992; Harding et al., 1995; Theron and Nel, 1997; Taraporewala et al., 2001), have begun to identify and determine the sequences of each of the 10 BTV genes of many BTV serotypes and the functionalities of the corresponding viral structural and non-structural proteins underlying much of the variability in different animals. The results of viral genomic and protein sequences, their replication cycles in different host cells, multifunction of the structural, and non-structural proteins, etc., can also be found in several BTV reviews (Barber et al., 1985; Campbell and Grubman, 1985; Roy, 1989, 1992, 1996; Eaton et al., 1990; Gorman, 1990; Roy and Gorman, 1990; Osburn, 1994; Huang and Li, 2000; Roy and Noad, 2006; Yang, 2009).

In our laboratory, we have sequenced the entire viral genomes of BTV 2, 11, 13, and 17, and some of BTV 10 genes (their accession numbers are shown in Table 1), established their genetic relatedness, identified various antigenic epitopes, and functional characteristics of several viral proteins, located some of the nucleic acid binding domains of viral proteins, and recently identified three anti-BTV compounds, and their mechanisms of action ( $\mathrm{Li}$ et al., 1987, 1989; Li and Yang, 1990, 1992; Hwang et al., 1992a,b, 1993, 1994; Yang et al., 1992a; Li and Hwang, 1992; Huang et al., 1993, 1995; Hwang and Li, 1993; Hayama and Li, 1994; Wang et al., 1996; Huang and Li, 1997, 2000; Fillmore et al., 2002; Xiao et al., 2004; Hu et al., 2008).

In addition to our continuous pursuit of the virolomic biosystems of BTVs, we have discovered their oncolytic activities that can selectively degrade human cancer cells both in vitro (Xiao et al., 2004; Hu et al., 2008) and in vivo (manuscript in preparation), but not normal human cells. Thus, greater attention is devoted in our lab to further explore and investigate the oncolytic activity of 
Table 1 | Available BTV genome sequence accession numbers.

\begin{tabular}{|c|c|c|c|c|c|}
\hline \multirow[t]{2}{*}{ Segment } & \multicolumn{5}{|c|}{ US Prototype bluetongue viruses } \\
\hline & 2 & 10 & 11 & 13 & 17 \\
\hline L1 & L20508 & X12819 & L20445\# & L20446\# & L20447\# \\
\hline L2 & * & M11787 & M17437 & $\begin{array}{l}\text { D00153 } \\
\text { L11874 }\end{array}$ & M17438 \\
\hline L3 & L19967\# & M22096 & L19968\# & L19969" & K02369 \\
\hline M1 & L08637\# & L13726\# & L08638\# & L08641\# & L08639\# \\
\hline M2 & M97680\# & Y00422 & M97681"\# & M97762 & X17041 \\
\hline M3 & X62283 & P07389 & L15424" & X54308 & X55359\# \\
\hline $\mathrm{S} 1$ & M38172" & P07886 & M32102\# & J04365" & X53693" \\
\hline S2 & L08673\# & D00500 & L08674\# & L08675\# & L08676\# \\
\hline S3 & L08668\# & L08669" & L08670\# & L08671\# & L08672\# \\
\hline S4 & L08628\# & M28981 & L08631"\# & L08629\# & L08630\# \\
\hline
\end{tabular}

*Published sequence but no accession number available in GenBank.

${ }^{*}$ Accession numbers provided by Dr. Joseph Li's laboratory.

BTV and identify the viral factors, events, and pathways with which BTVs can selectively degrade human cancer cells. These data can be used for potential treatment of human cancers after additional in vivo and subsequent clinical studies.

\section{UNIQUE NOVEL ONCOLYTIC ACTIVITIES OF THE BTV VIROLOMIC SYSTEM}

Bluetongue viruses, pathogenic only to domestic cattle and wild ruminants (Barratt-Boyes and MacLachlan, 1995; Tsuboi and Imada, 1997), are non-pathogenic to humans (Xiao et al., 2004; Hu et al., 2008) and thus, humans do not have pre-existing antibodies to BTVs (Jeggo et al., 1983; Barratt-Boyes and MacLachlan, 1995; Dong et al., 1998). Not only can BTV be grown easily in vitro (Jameson and Grossberg, 1981; Du, 1985; Samal et al., 1985; Sundin and Mecham, 1989; Dong et al., 1998; Wechsler and McHolland, 1998; Chen et al., 1999; Prasad et al., 1999; Xue, 2001; Lei et al., 2004; Xiao et al., 2004; Liang et al., 2006; Hu et al., 2008), it has powerful oncolytic activity against many different in vitro cultured cancer cell lines (Chen et al., 1999; Xiao et al., 2004; Hu et al., 2008), such as A498 human kidney cells (ATCC: HTB-4), HEP-G2 human liver cells (ATCC: HB-8065), A549 human lung epithelial cells (ATCC: CCL-185), baby hamster kidney cells (BHK-21), monkey kidney (Vero) cells (Ramig et al., 1989), mouse fibroblast cells (NIH 3T3), SPC-A-1 cells (Lei et al., 2004), MA 782 cells (Liang et al., 2006), and in mouse models. No normal human cells such as the primary human embryo lung fibroblast (HEL) and primary murine embryos fibroblast (MEF) have ever been successfully infected by BTV (Dong et al., 1998; Chen et al., 1999; Lei et al., 2004; Xiao et al., 2004; Liang et al., 2006; Hu et al., 2008) and thus, humans are normally sero-negative. Madin-Darby canine kidney (MDCK) which is sensitive to reovirus apoptosis also proved resistant to BTV infection except in high MOI (unpublished data). BTVs can also infect cultured insect cells (King and Alders, 1985; Samal et al., 1987; Guirakhoo et al., 1995; Mullens et al., 1995; Mertens et al., 1996; Xu et al., 1997; Tan et al., 2001).

In the last decade, our lab and collaborators have used both cell culture systems (Dong et al., 1998; Chen et al., 1999; Lei et al., 2004; Xiao et al., 2004; Liang et al., 2006; Hu et al., 2008) and mice (manuscript in preparation) to investigate and determine the oncolytic activities and capacities of BTVs and their selective degradation of human cancer cells as potential treatment of human cancers. Human cancer cell lines such as Hep-3B and Hep-G2, A549, A498, SPC-A-1, and MA 782 cells infected with BTV 10, 11, 13, 17, and $\mathrm{HbC}_{3}$ at various MOIs exhibited the following easily detected characteristics $36 \mathrm{~h}$ post-infection (pi) but not in HEL and MEF cells in multiple determinations (Xiao et al., 2004; Hu et al., 2008). Briefly:

1. Between 70 and $90 \%$ cytopathic effects (CPE) were readily observed and detected along with cellular apoptosis and necrosis in many human cancer cell lines.

2. Various degrees of morphological and cellular damage could be visualized by either light, confocal, or electron microscopy (EM).

3. Viral particles could be seen intra-cellularly and at the plasma membrane.

4. Cellular dilated endoplasmic reticulum, nuclear chromatin condensation, and cytoplasmic shrinking were readily detected and easily observed in EM.

5. BTV viral genomic ds-RNA fragments and viral mRNAs could be found in BTV-10, 13, 17, and $\mathrm{HbC}_{3}$ infected human cancer cells, but not in normal HEL or MEF cells by gel electrophoresis, ELISA, RIP, Western blots, PCR, and qRT-PCR (Tiwari et al., 2000).

6. The survival rate of several human cancer cell lines was low if high MOI was used.

7. Primary HEL and MEF cells survived very well for 6-9 days independent of the MOI used for testing.

8. Human cancer cells infected with BTVs had more efficient viral replication and provided higher viral progeny yields.

9. Selective cell cycle arrest at sub-G1 peak in several human cancer cells infected with BTV-10 (Hu et al., 2008) and HbC3 similar to the reovirus-induced G2/M cell cycle arrest (Poggioli et al., 2000).

After tumor cells were grown in culture and then injected as xenografts into mice (eight mice/sample), tumors developed and all these mice died in less than 8 days (Preliminary data). When $0.1 \mathrm{ml}$ of BTVs with different MOIs in sterile phosphate-buffered saline (PBS) was injected at three different sites of each xenograft, the sizes of tumors in mice were reduced $60-85 \%$. Most mice with the reduced tumors survived more than 35 days before they were sacrificed for tissue and organ samples (kidney, lung, liver, heart .... etc.) to detect the presence of BTVs. No BTVs and CPEs were found in these tissue and organ samples. There was also no weight loss (manuscript in preparation). The outcomes of three independent repetitions were similar. Thus, BTVs' selective cytotoxic effects to human tumor cells in vitro and partially in vivo have been clearly indicated and demonstrated. Further in vivo research and clinical studies are now in progress to document and investigate this unique oncolyitc potential of BTVs which will provide us better and safer application in humans either in monotherapy or combination therapy in the near future.

\section{INFLAMMATORY MEDIATORS ARE ELEVATED DURING BTV INFECTION}

Bluetongue viruses administration has been shown to cause cell death and apoptosis in several cell lines as well as in several human tumor cell lines (Wechsler and McHolland, 1998; Xiao et al., 2004; 
Liang et al., 2006; Hu et al., 2008). The mechanism by which tumor reduction occurs is still unknown. However, in experiments with cultured human cancer cells, the cells detached and died progressively throughout BTV infection. All BTV genes are transcribed and BTV proteins are expressed during infection.

In the analysis of secreted analyte expression, cytokine and chemokine levels from mock- and BTV-17 infected cells were determined using Multiplex Immunoassay Kits and reagents supplied from Quansys Biosciences (Logan, UT, USA), according to the supplier's protocol. Twenty-five analytes were tested and these included IL-1a, IL-1b, IL-2, IL-4, IL-5, IL-6, IL-8, IL-10, IL-12p40, IL-12p70, IL-13, IFN $\gamma$, TNF $\alpha$, TNF $\beta$, TGF-b1, MCP-1, RANTES, ANG2, HGF, TIMP, TPO, VEGF, PDGF, FGF-basic, and CRP (manuscript in preparation).

Of the 25 analytes tested for during infection, only seven were found to be expressed from five cell lines: A498 human kidney cells, HEP-G2 human liver cells, A549 human lung epithelial cells (ATCC: HTB-4, HB-8065, CCL-185, respectively), BHK-21 cells, or Vero cells. Of these seven analytes, five were found to be consistently elevated upon BTV infection, with the expression pattern consistent among cell lines. These are IL-6, IL-8, MCP-1, RANTES, and FGF $\beta$. The levels of VEGF and TIMP were similar in control and BTV-infected cells. However, A498 kidney cells responded to infection with the greatest secretion of cytokines, followed by A549 lung cells while HEP-G2 liver cells secreted the least amount of cytokines.

Polyinosine:polycytosine (poly I:C) is a synthetic ds-RNA that has been used to assess the role of ds-RNA segments of many ds-RNA viruses in vitro since it can induce differential interferon and cytokine production (Der et al., 1998; Diebold et al., 2003; Chiang et al., 2006). However, poly I:C alone did not cause cell death or have a significant impact on cytokine or chemokine expression in BTV-infected human cancer cell lines. Only IL-6 and IL- 8 were found to be significantly elevated during poly I:C treatment. Increases in IL- 6 and IL- 8 were observed only in kidney cells (A498 and Vero) and were most prevalent in samples treated with $1 \mu \mathrm{g} / \mathrm{ml}$ poly I:C. The other cytokines MCP-1, RANTES, and FGF $\beta$ were all at expression levels comparable to the placebo treated cells.

With the identification of some of the antigenic epitopes of various BTV proteins (Wang et al., 1972; Geysen et al., 1985; Fukusho et al., 1987; Gould et al., 1988a, 1994; Grieder and Schultz, 1989; Geysen, 1990; Li and Yang, 1990, 1992; Marshall and Roy, 1990; Mecham and Jochim, 1990; Eaton et al., 1991; Rossitto and MacLachlan, 1992; Du Plessis et al., 1994, 1995; Schoehn et al., 1997; Nagesha et al., 2001), BTV immunity has only been studied partially in the last two decades because of lack of supporting funding and reliable immune assays (Jeggo and Wardley, 1982a,b; Gibbs et al., 1983; Jeggo et al., 1983; Campbell and Grubman, 1985; Stott et al., 1985; Fukusho et al., 1987; Huismans et al., 1987a; Marshall and Roy, 1990; Martyn et al., 1991; Li and Hwang, 1992; Jones et al., 1996, 1997; Lin and Zhou, 1996; Wade-Evans et al., 1996; Odeon et al., 1999; Prasad and Minakshi, 1999; DeMaula et al., 2000; Roy, 2003). With the recent development of more reliable immune assays and microarrays, we have found that BTV can induce inflammatory cytokine expression in immortalized human kidney, lung, and liver cells and subsequently kill the infected cell with cell line-dependent severity. Analysis of results from the cytokine profiles and expression levels in these five cell lines indicated that human tumor cells and tumor reduction might be a result of the combined effects of direct viral induced cell death and recruitment of T-lymphocytes (Jeggo and Wardley, 1982a,b; Jones et al., 1996, 1997) to the tumor through elevated cytokine/chemokine production (Shmulevitz et al., 2005, 2010). Very high levels of pro-inflammatory cytokines were secreted from BTV-infected cells and cytokine levels secreted from each of the seven cell types were directly proportional to the measured death of infected cells. Thus, we hypothesize that the cell death and cytokine expression are related and may be caused by shared signaling pathways or events. These pathways/events are currently under investigation. If these same events occurred in human tumors, BTV would be expected to reduce tumor size in infected patients by directly causing infected human cancer cell death and by inducing cytokine expression from the tumor that would lead to lymphocyte recruitment to the site of the tumor. Thus, BTV has the therapeutic potential in cancer because of its selective ability to cause preferential apoptosis of various human cancer cell lines and tumors.

\section{PROGRESS AND PERSPECTIVES OF ONCOLYTIC VIRUSES}

Ideal oncolytic viruses should have essential survival data, systemic effect, resist immune system clearance, targeted delivery, and distribution, be highly mobile for intravenous spread, travel to and kill distant metastases, have a high rate of replication to stay ahead of immune system clearance, tolerable toxicity, and side effects, etc. Systemic efficacy is the ability of a virus to find and attack distant metastases. Systemic delivery makes sense in cancer where primary tumors and metastases are dispersed. However, systemic approach in cancer is a big problem because we do not have a good target specific delivery device that would facilitate uptake specifically for certain cells. There is no transport vehicle to target specific cell type yet. Oncolytic viruses can become a radical approach to treat cancer. If this can be achieved, then it would be better than the current and conventional therapies. However, it is very difficult to get enough control patients in clinical trials and to get biopsies from different tissues, organs and tumors after the oncolytic virus treatments to determine the efficacy or survival of most oncolytic viruses. Oncovirologists consider oncolytic virus as a dark horse treatment but not a dead one since they know that many anti-cancer agents appear to be actively effective in lab cultures and animal models but failed in human trials.

Many oncolytic viruses (Norman and Lee, 2005; Alain et al., 2006, 2007; Kim et al., 2006; Shen and Nemunaitis, 2006; Burroughs et al., 2007; Qi et al., 2007; Ribacka et al., 2008; Cripe et al., 2009; Ou and Yen, 2010) that are currently in phase I/II/III human clinical trial status include adenovirus, vaccinia virus, coxsackie virus, reovirus, Newcastle disease virus, herpes simplex virus 1, measles virus, and Seneca Valley virus (Burroughs et al., 2007). In 2007, the only oncolytic virus approved for phase III clinical trials in China was the adenovirus (H101) with E1B deletion produced jointly by the Sunway Biotech of China and Onyx Pharmaceuticals of 
Emeryville, CA, USA (Privilege communication). Since mid-2005 to the end of 2010, several other oncolytic viruses have also been approved for phase III clinical trials primarily outside US as briefly described below. Thus, cancer therapy with oncolytic viruses has survived and revived, and this unique approach is poised for a comeback (Aghi and Martuza, 2005; Norman and Lee, 2005; Alain et al., 2006; Liu, 2006; Liu et al., 2007).

The results of the last $10-15$ years of investigation generated by researchers have increased interest in oncolytic viruses. Investigators have generated and obtained some genetically modified viruses with greater oncolytic potentials (Aghi and Martuza, 2005; Norman and Lee, 2005; Alain et al., 2006; Liu, 2006; Liu et al., 2007). A significant effort is underway to understand the genetic and mechanistic basis of cancers, selective degradation of cancer cells by these oncolytic viruses, and their effects on downstream cellular events and pathways (Strong et al., 1998; Norman et al., 2004; Vorburger et al., 2004; Aghi and Martuza, 2005; Norman and Lee, 2005; Shmulevitz et al., 2005, 2010; Alain et al., 2006; Liu, 2006; Kim et al., 2007; Liu et al., 2007; Marcato et al., 2007; Hu et al., 2008; Cripe et al., 2009; Hill and Lee, 2010; Ou and Yen, 2010; Thirukkumaran et al., 2010). Increasing attention is being paid to protein families like proteases, caspases, and kinases which play critical roles in cancer.

Current therapeutic approaches for human cancer include the regimen of selective surgery, high dose but cytotoxic chemotherapy with two to three drugs and radiation. These approaches are not very effective to combat the increasing numbers of human cancers. Using oncolytic viruses generates a paradigm shift from current cancer treatment using chemotherapy and radiation which typically destroy both normal and cancer tumor cells. As we learn more about cancer biology and oncolytic viruses, new strategies for treating cancers are rapidly evolving. Uses of oncolytic virus alone or with synergistic anti-cancer drugs or irradiation in human clinical trials are currently under consideration or in progress.

Reovirus leads the field of oncolytic viruses and positive clinical trials are very encouraging (Strong et al., 1998; Norman et al., 2004; Norman and Lee, 2005; Shmulevitz et al., 2005, 2010; Alain et al., 2006; Kim et al., 2007; Marcato et al., 2007; Cripe et al., 2009; Hill and Lee, 2010; Thirukkumaran et al., 2010). Other companies and institutes are not far behind. In mid-May 2010, researchers of the University of Helsinki and Oncos Therapeutics have treated 200 patients with their "modified" GMCSF armed oncolytic adenovirus which exhibited antitumor immunity that recruited natural killer cells and induced tumor-specific cytotoxic T-cells with strong efficacy and safety. The media report indicated that its clinical benefit is about $45 \%$ according to the RECIST criteria with no grade four to five side effects detected. This represents an extension of their initial investigation in 2008.

With these successful applications and those from other oncolytic viruses, we can now add the simple but oncolytic BTV as a key component to the armamentarium of oncologists to combat and destroy the insidious cancer cells since BTVs have similar characteristics and additional subtle advantages over reovirus and other oncolytic viruses.
COMPARATIVE VIRATHERAPY AND VIRATHERAPEUTICS OF REOVIRUS (Strong et al., 1998; Norman et al., 2004; Norman and Lee, 2005; Shmulevitz et al., 2005, 2010; Alain et al., 2006; Kim et al., 2007; Marcato et al., 2007; Cripe et al., 2009; Hill and Lee, 2010; Thirukkumaran et al., 2010) AND BTV (Dong et al., 1998; Chen et al., 1999; Lei et al., 2004; Xiao et al., 2004; Liang et al., 2006; Hu et al., 2008)

Bluetongue viruses and reovirus are more advantageous than the genetically modified oncolytic DNA viruses since the integration of viral ds-RNA genome into the host cell genome have not been shown or reported. Since humans are sero-negative to BTVs, potential future use of BTV to degrade human cancer by direct intratumoral injection to degrade the injected tumors will not be inhibited by pre-existing immune components within human cancer cells. Thus, BTV is potentially better than Reovirus in initial oncolytic applications. The current mechanisms of oncolytic Reovirus toward human cancer cells have recently been summarized (Strong et al., 1998; Norman et al., 2004; Norman and Lee, 2005; Shmulevitz et al., 2005, 2010; Alain et al., 2006; Kim et al., 2007; Marcato et al., 2007; Cripe et al., 2009; Hill and Lee, 2010; Thirukkumaran et al., 2010).

Genetically modified reovirus serotype 3, but not types 1 and 2 , is a proprietary product called Reolysin produced by Reolytics Biotech, Inc. Data for cancer treatment with this agent from the last decade in animal models and lately in phase I/II human clinical trials have shown encouraging indications of its potential oncolytic activities in cancer cells bearing an activated Ras pathway. Phase III human clinical trials have been approved and initiated in 2009. However, the pre-existing anti-reovirus sera in humans worldwide can trigger greater immune responses against this virus, reducing its efficacy and effectively shutting down its potential oncolytic treatment. Uses of oncolytic BTV have greater advantages over reovirus since no anti-BTV serum is detected in most people globally. Even though BTV injected into tumors can activate dendritic cells for early detection of viral infection, it will take 10-14 days before adaptive immune responses can be generated against BTVs which can eradicate xenografted tumor cells in mice in less than 10 days (preliminary data).

Oncolytics Biotech at Calgary, AB, Canada showed the uses of Reovirus (Reolysin) plus cisplatin, a standard chemotherapy agent in both cultured melanoma cells and a mouse model. The combined uses of Reolysin and cisplatin were much better than either of these two agents alone since they appeared to work synergistically (Abstract of the 4th International Symposium on the "Treatment of Cancers with Oncolytic Viruses" at Scottsdale, Arizona March 15-17, 2007). Furthermore, they had also showed that simultaneous and combined uses of Reolysin and gemcitabine could completely eradicate the transplanted colon cancer in four of the five mice (Abstract of the American Association for Cancer Research (AACR) Annual Meeting in April 2007).

Since mid-April, 2007, Oncolytics Biotech has demonstrated some success in multiple Phase II trials with several medical centers in the UK and US, administering intravenous Reolysin to patients with sarcomas that have metastasized to the lung. Multiple clinical trials for other tumors with the US National Cancer Institute (NCI) were conducted in late 2007. Clinical trials of head and neck 
cancers began in mid-August 2010. This will help to determine whether Reolysin can migrate systemically to metastasized tumor sites and exhibit its oncolytic activity.

Oncolytics Biotech has expended more than 65 million dollars and a decade of genetic modifications of Reolysin before human clinical trials were approved. Similar and greater expenditures have also been made by other companies and institutes in the last 12-15 years to develop different oncolytic viruses with tremendous personnel efforts before some clinical trials are approved and conducted. We strongly believe that BTV is the front runner of the next generation oncolytic viruses since it needs no genetic modifications and attenuation, and carries no payloads. It can grow fast and spread easily within many human cancer cells. Since there is no pre-existing neutralizing antibody against BTV in humans, they should be undetected nor immunologically inhibited in the initial injection alone or with anti-cancer agents. In addition to the comparison of the oncolysis of human cancer cells by reovirus and BTV as shown in Table 2, BTV has additional advantages. Briefly:

1. Since BTV does not infect normal human cells, we do not have to suppress the immune system before use. However, it might affect subsequent injections.
2. BTV is harmless to normal human cells which have active p53. However, BTV will attack human tumor cells that have impaired $\mathrm{p} 53$.

3. BTV is very stable since it can be stored at $\mathrm{pH} 8.2-8.4$ at $4^{\circ} \mathrm{C}$ for over 20 years with only $5-10 \%$ loss of infectivity (unpublished data). It is also stable at room temperature at this $\mathrm{pH}$ for 3-4 weeks. Thus, it can be shipped by air-mail globally without significant loss of its infectivity and oncolytic activities (unpublished data).

4. BTV correlates well with measurement of viral level and tumor responses. Thus, this is a direct effect toward cancer cells. 2-D gel electrophoresis and the 3-D assay (Lam et al., 2007) for the measurement of BTV-induced oncolysis are currently under optimization and further development and adaptation.

5. BTV infection of many cultured human tumor cells has led to the production of many "inflammatory" cytokines such as TNF-alpha and IL-6 which strongly activate the kinase activity of p38 MAPK and ERK1/2. These cytokines also assist the subsequent activation of p38-dependent MAPK and PKR pathways which can bring about the necrosis and apoptosis of cancer cells. This strongly suggests that BTV

\section{Table 2 | Comparison of oncolytic reovirus and bluetongue virus.}

\section{Reovirus*}

About $100 \times$ more efficient replication in RAS-transformed cancer cells

Produce potent and specific CPEs

About $3 \times$ more efficient proteolytic disassembly (uncoating) because more active endosomal and lysozsomal proteases (cathepsins B and L) are present in cancer cells

Produce $4 \times$ more infectious progeny than non-infectious defective interfering particles

About 9x more caspase-induced apoptosis

Caspase-independent apoptosis (NA)

Poly (I:C) did not prevent reovirus infection

Pro-inflammatory cytokines (NA)

Reovirus persistently infected Raji cell, did not reduce xenograft tumor in mice and

"cure" cells (Raji)

HTR1 cell is a highly reovirus-resistant Fibrosacoma cell derived from HT1080. It has reduced cathepsin $\mathrm{B}$ activity and it constrains reovirus oncolysis

Persist in tumor through days (NA)

Toxicity tests are well tolerated

Systemic delivery (some success)

Required specific genetic modifications

Humans have pre-existing anti-reovirus sera

No integration of viral genome into host cell genome

\section{Bluetongue virus}

$5,000 \times$ more efficient replication in RAS-transformed cancer

cells

Similar results

Determination in progress

Determination in progress

Has caspase-3 induced apoptosis

Presence of Caspase-independent apoptosis

Similar results

Higher levels of pro-inflammatory cytokine production

Data Not Available (NA)

No BTV-resistant human cancer cells have not been detected yet

Persist in human tumor xenografts in mice through day 30 from a single injection

Similar preliminary results

Work in Progress

No modification is required

Humans have no pre-existing anti-BTV sera

No integration of viral genome into host cell genome

Work under planning and in progress 
can prime and direct the immune system of cancer patients against certain solid tumors such as breast and prostate cancer.

6. Repeat screening of over 500 human cytokines using biotin label-based cytokine antibody array is currently in progress and data are under comparative analysis.

7. Construction and rescue of recombinant infectious BTV (Boyce and Roy, 2007) expressing the enhanced green fluorescent protein (eGFP), using a protocol similar to one recently published by our lab for human parainfluenza virus type 3 (Roth et al., 2010) will be initiated shortly.

\section{DIFFERENT MECHANISMS BY WHICH ONCOLYTIC REOVIRUS AND BTV CAN SELECTIVELY DEGRADE CANCER CELLS}

An activated Ras/RalGEF/p38 pathway is potentially involved with the permissiveness of host cells to Reovirus infection (Norman et al., 2004; Shmulevitz et al., 2005; Alain et al., 2007; Kim et al., 2007; Marcato et al., 2007). It has been shown that the c-K-ras gene inside the lung carcinoma cell line A549 we used has mutation at codon 12 (Valenzuela and Groffen, 1986). Since the Ras/RalGEF/ p38 signal pathway inside the A549 cell has been activated, this might allow BTV to degrade human tumor cells efficiently similar to reovirus (Stott et al., 1985; Shmulevitz et al., 2005, 2010; Kim et al., 2007; Marcato et al., 2007).

We have further hypothesized that the genetic alterations/ mutations of different human cancer cells, such as signals within a Ras-activated pathway, play a key role in the susceptibility of different oncolytic viruses in addition to specific viral receptors which might be present in human cancer cells but not in normal human cells. Identification of BTV receptor(s) on the surface of human cancer cells is also currently in progress. Comparison of oncolytic potentials between reovirus and BTV is summarized in Table 2.

With regard to the potential cytotoxic effect mechanisms of BTVs, the GP5 protein of BTV identified by our lab (Li and Yang, 1992; Yang and Li, 1992, 1993; Yang et al., 1992a) has recently been shown to induce or trigger apoptosis in mammalian cells (Mortola et al., 2004). Furthermore, the non-structural BTV protein, NS-3, has been shown to be a "viroporin," the polymerization of which forms pores on the surface of BTV-infected cells, leading to severe cellular leakage, and potential cell death (Han and Harty, 2004). We hypothesize that these two BTV proteins and other(s) are involved with the cytotoxic effect of human cancer cells after BTV infection. Individual BTV gene "silencing" with RNAi to determine the contribution of each of the BTV gene products to onclysis of human cancer cells are also in progress.

\section{TOLL-LIKE RECEPTOR SIGNALING AND BTVs}

The protein Toll (means "weird" in German) was discovered in the fruit fly Drosophila melanogaster in 1980s. It is a transmembrane signal reporter protein that functions primarily in development. However, if mutations in Toll occurred in the fruit fly, the infection by Aspergillus fumigates (a fungus) is lethal. Toll-related molecules involved with human innate immunity and coined as toll-like receptors (TLRs) were then discovered in mid-1990s by Ruslan Medzhitov and Charles Janeway (Medzhitov and Janeway, 2002; Norman et al., 2004). TLRs are molecular pattern recogni- tion receptors and can recognize molecules that are broadly shared by many pathogens. Thus, TLRs pathways play a key role in both innate immunity and normal immune physiology that can sense different pathogens and cancer cells. We hypothesize that some of the TLRs have mutated in many cancer cells.

To determine whether mutated TLRs are involved with the recognition of BTVs, we have initiated the "silencing" of each 1 of the 10 known human TLRs TLR- 1-10 using RNAi. Human cancer cell lines, A498 and HEK 239, are transfected with DNA plasmids containing siRNA sequences against human TLRs (Invivogen, CA, USA). Preliminary data indicated that endosome-located TLR-3 which specifically recognizes ds-RNA is potentially involved since cells transfected with this TLR-3 RNAi plasmid produced substantially less BTV 17 and 10 progeny. Cells transfected with TLR-2, 4, 7, 8 , and 9 RNAi plasmids produced slightly less viral progeny in these two human cancer cell lines. Similar results are also found in A549 and Hep-G2 cells. Experiments are now underway to determine what types of mutation are in the TLR-3 in these four human cancer cell lines and this might provide a potential explanation of why normal human cells are not infected by BTV because the regular TLR-3 has not been modified nor mutated. Several signal pathways related to TLRs are currently under screening using Pathway Screen Arrays (Qiagen/SABiosciences).

\section{CONCLUSION}

Human cancers can be divided into two major types, 90 and 10\% of which are solid (carcinoma and sarcoma) or liquid (leukemia) tumors, respectively. There have been widely unrealistic claims of personalized cancer medicine in the last decade. Recent data and epidemiological analysis of many tumors reveal that most FDAapproved cancer therapeutic drugs can only provide small incremental improvement and survival to cancer patients. Companies that make many unrealistic claims for human cancer cures in scientific tabloid media do so strictly for financial reasons since these expensive cancer drugs can generate great revenues via physicians who make drug recommendation and to whom drug companies provide substantial and financial "kick-back" incentives. Interestingly, primary tumors are heterogeneous and they do not kill most cancer patients. However, the $90 \%$ of deaths of cancer patients are primarily caused by those cancer stem cells that have metastasized to other regions to form metastatic tumors.

Humans are sero-negative toward BTVs since BTVs do not infect normal human cells. Infection and selective degradation of several human cancer cell lines, but not normal cells, in vitro by five US BTV serotypes have been investigated by our lab for the last few years when BTV oncolytic potential was discovered. We have also recently found that direct single injection of oncolytic BTV into the human tumor xenografts in mice, have led to cytotoxic destruction and preferential lysis of cancer cells within the xenograft but not in normal healthy human or mouse cells (preliminary data). Thus, oncolytic BTVs are safer and more effective than most current cancer treatments. However, we believe that oncolytic BTV is not a "stand-alone" therapeutic and that simultaneous combination of BTV with either radiation or chemotherapy can obliterate the tumors more rapidly and extensively. Cancer patients should have fewer side effects since small dosage radiation and anti-cancer drugs are used for this combined treatment. 
Related to the oncolytic BTVs, the following questions have been frequently asked: Is widely curing cancer by oncolytic viruses possible or just hype? What are some of the mechanisms of the selective degradation of human tumors? Will this become a therapeutic modality bridging the lab to bedside? Will the data and results be useful and informative to clinical medicine? Will this scientific innovation transform into health gain for humanity? How "big" is the gap between in vitro/in vivo studies and human application? Is oncolytic BTV a vital alternative for cancer therapy? What are the pathways BTV used to carry out this task? How long would it take to translate BTV oncolysis to medicine? Overall, we believe that the oncolytic ability of BTV represents a significant potential to selectively degrade human cancer cells alone and would even be greater when combined with simultaneous anti-cancer drug and radiation treatment.

Our group and collaborators are currently engaged in several types of investigations with these goals: (1) Study the mechanistic basis of lung, kidney, and liver cancer destruction by BTVs, (2) Examine and determine biological profiles of three types of solid tumors after BTV infection, (3) Correlate the responses of these human cancer cells to changes at the cellular DNA, RNA and protein level, and (4) Construction and rescue of an infectious recombinant BTV 17 expressing the enhanced eGFP using the method that we have developed for the human parainfluenza virus type 3 (Roth et al., 2010) with BTV ds-RNA fragments (Kowalik et al., 1990b; Boyce and Roy, 2007), the success of which can further reveal the oncolytic pathways used by BTVs.

Taking the next step in the investigation of BTV oncolysis is very challenging since no one can individually excel in all the technical, scientific, and clinical avenues involved in this endeavor. Our ongoing in vitro work with different human cancer cell lines will assist us in elucidating the potential mechanisms of the BTV oncolytic activities. No CPE was detected nor viral

\section{REFERENCES}

Aghi, M., and Martuza, R. L. (2005). Oncolytic viral therapies - the clinical experience. Oncogene 24, 7802-7816.

Alain, T., Kim, M., Johnston, R. N., Urbanski, S., Kossakowska, A. E., Forsyth, P.A., and Lee, P.W. K. (2006). Translational therapeutics. $\mathrm{Br}$. J. Cancer 95, 1020-1027.

Alain, T., Kim, T. S. Y., Lun, X., Liacini, A., Schiff, L. A., Senger, D. L., and Forsyth, P. A. (2007). Proteolytic disassembly is a critical determinant for reovirus oncolysis. Mol. Ther. 15, 1512-1521.

Bansal, O. B., Stokes, A., Bansal, A., Bishop, D., and Roy, P. (1998). Membrane organization of bluetongue virus nonstructural glycoprotein NS3. J. Virol. 72, 3362-3369.

Barber, T. L., Jochim, M. M., and Osburn, B. I. (1985). Bluetongue and related orbiviruses. Prog. Clin. Biol. Res. 178, 746-750.

Barratt-Boyes, S. M., and MacLachlan, N. J. (1995). Pathogenesis of bluetongue virus infection of cattle. J. Am. Vet. Med. Assoc. 206, 1322-1329.
Basak, A. K., Grimes, J. M., Gouet, P., Roy, P., and Stuart, D. I. (1997). Structures of orbivirus VP7: implications for the role of this protein in the viral life cycle. Structure 5, 871-883.

Boyce, M., and Roy, P. (2007). Recovery of infectious bluetongue virus from RNA. J. Virol. 81, 2179-2186.

Bremer, C., Thomas, C. P., and Roy, P. (1992). "Interaction of ssRNA with NS2, the non-structural phosphoprotein of bluetongue virus and formation of inclusion bodies," in Bluetongue, African Horsesickness and Related Orbiviruses, eds T. E. Walton and B. I. Osburn (Roca Raton, FL: CRC Press), 393-403.

Burroughs, K. D., Hales, L. M., Ganesh, S., Jones, B. H., Idamakanti, N., Hay, C., Li, S. S., Skele, K. L., Sherk, C., Vasko, A.-J., Yang, J., Watkins, D. N., Rudin, C. M., and Hallenbeck, P. L. (2007). Seneca valley virus (SVV001), a systemically deliverable oncolytic picornavirus, and the treatment of neuroendocrine cancers. J. Natl. Cancer Inst. 99, 1623-1633.

progeny obtained when several primary human cell lines were infected by BTV. This represents a potential benefit in humans. When xenografts implanted in mice were injected directly with BTV, no pathological damages were detected in any tissue or organs 7-21 days post-infection (preliminary data). Thus, the potential risks of BTV oncotherapy is substantially lower than risks associated with other oncolytic viruses. However, this author sincerely hopes that expert advice and suggestions will be forthcoming from different "champions" after they have read this brief review.

\section{ACKNOWLEDGMENTS}

I want to thank all my 20 former USU graduate students, postdoctoral fellows, and over 70 undergraduate research fellows who have carried out all the BTV investigations either independently or as a team with their excellent laboratory, technical and computer assistance. Without their devoted contributions, our BTV research would not have been performed in US. The participation of over 25 collaborators in China led by Professor Chang-Yuan Dong and Dr. Jun $\mathrm{Hu}$ are essential to our BTV research. The initial in vivo xenograft studies, led by $\mathrm{Dr}$. Jun $\mathrm{Hu}$, are significantly supportive. I express my regret and apologies to all the global colleagues in BTVrelated investigations since not all of their systemic studies, research investigations, and publications could be cited in this manuscript and in the References due to space restriction of this journal. I also extend my sincere appreciation to several anonymous global colleagues and reviewers who had given me periodic advice, suggestions, and insights that have continuously enhanced our BTV research. Some of their inputs have also improved this review manuscript. BTV research in our lab has been supported continuously in parts by grants from USDA and by the Utah Agricultural Experiment Station Project 537 and 538. This paper was approved as UAES journal paper \# 7913.

Campbell, C. H., and Grubman, M. J. (1985). Current knowledge on the biochemistry and immunology of bluetongue. Prog. Vet. Microbiol. Immunol. 1, 58-79.

Carr, M. A., de Mattos, C. C., de Mattos, C. A., and Osburn, B. I. (1994). Association of bluetongue virus gene segment 5 with neuroinvasiveness. $J$. Virol. 68, 1255-1257.

Chen, X., Yan, Y. F., Dong, C. Y., Chen, B. P., Tu, P., and Wang, F. J. (1999). The characteristics of the propagation, purification and serology of bluetongue virus $\mathrm{HbC}$ strain. Acta Acad. Med. Hubei 20, 179-191.

Chiang, E. T., Persaud-Sawin, D.-A. Kulkarni, S., Garciaq, J. G., and Imani, F. (2006). Bluetongue virus and double-stranded RNA increase human vascular permeability: role of p38 MAPK. J. Clin. Immunol. 26, 406-416.

Chuma, T., Le Blois, H., Sanchez-Vizcaino, J. M., Diaz-LaViada, M., and Roy, P. (1992). Expression of the major core antigen VP7 of African horsesickness virus by a recombinant baculovirus and its use as a group-specific diagnostic reagent. J. Gen. Virol. 73, 925-931. Cowley, J.A. (1992). Nucleotide sequence of the genome segment encoding nonstructural protein NS1 of bluetongue virus serotype 20 from Australia. Virus Genes 6, 387-392.

Cowley, J. A., and Gorman, B. M. (1987). Genetic reassortants for identification of the genome segment coding for the bluetongue virus hemagglutinin. $J$. Virol. 61, 2304-2306.

Cowley, J. A., and Gorman, B. M. (1989). Cross-neutralization of genetic reassortants of bluetongue virus serotypes 20 and 21. Vet. Microbiol. 19, 37-51.

Cowley, J. A., and Gorman, B. M. (1990). Effects of proteolytic enzymes on the infectivity, haemagglutinating activity and protein composition of bluetongue virus type 20. Vet. Microbiol. 23, 137-152.

Cripe, T. P., Wang, P. Y., Marcato, P., Mahller, Y. Y., and Lee, P. W. K. (2009). Targeting cancer-initiating cells with oncolytic viruses. Mol. Ther. 17, 1677-1682. 
de Mattos, C.C., de Mattos, C.A., Osburn, B. I., Ianconescu, M., and Kaufman, R. (1991). Evidence of genome segment 5 reassortment in bluetongue virus field isolates. Am. J. Vet. Res. 52, 1794-1798.

DeMaula, C. D., Bonneau, K. R., and MacLachlan, N. J. (2000). Changes in the outer capsid proteins of bluetongue virus serotype ten that abrogate neutralization by monoclonal antibodies. Virus Res. 67, 59-66.

DeMaula, C. D., Jutila, M. A., Wilson, D. W., and MacLachlan, N. J. (2001). Infection kinetics, prostacyclin release and cytokine-mediated modulation of the mechanism of cell death during bluetongue virus infection of cultured ovine and bovine pulmonary artery and lung microvascular endothelial cells. J. Gen. Virol. 82, 787-794.

Der, S. D., Zhou, A., Williams, B. R., and Silverman, R.H. (1998). Identification of genes differentially regulated by interferon alpha, beta, or gamma using oligonucleotide arrays. Proc. Natl. Acad. Sci. U.S.A. 95, 15623-15628.

Devaney, M.A., Kendall, J., and Grubman, M. J. (1988). Characterization of a non-structural phosphoprotein of two orbiviruses. Virus Res. 11, 151-164.

Diebold, S. S., Montoya, M., Unger, H., Alexopoulou, L., Roy, P., Haswell, L. E., Al-Shamkhani, A., Flavell, R., Borrow, P., and Reis e Sousa, C. (2003). Viral infection switches non-plasmacytoid dendritic cells into high interferon producers. Nature 424, 324-328.

Dock, G. (1904). Influence of complicating diseases upon leukemia. Am. J. Med. Sci. 127, 563-592.

Dong, C. Y., Chen, D. E., Chen, X., Cao, Z . H., Duan, J. R., and Liu, Y. H. (1998). Isolation of Bluetongue Virus Strain $\mathrm{HbC}$ and its Biological Characters. The Clinic Medicine Research. Beijing: Chinese Population Publishing House, 180-182.

Du, P. (1985). Medical Experimental Virology. Beijing: Beijing-People's Military Medical Press, 102-109.

Du Plessis, D. H., Romito, M., and Jordaan, F. (1995). Identification of an antigenic peptide specific for bluetongue virus using phage display expression of NS1 sequences. Immunotechnology 1,221-230.

Du Plessis, D. H., Wang, L.-F., Jordaan, F. A., and Eaton, B. T. (1994). Fine mapping of a continuous epitope on VP7 of bluetongue virus using overlapping synthetic peptides and a random epitope library. Virology 198, 345-349.

Dunn, S. J., Hsu, D., Zee, Y. C., and Stott, J. L. (1991). Complete nucleotide and deduced amino acid sequence of genome segment 5 encoding the outer capsid protein, VP5, of a U.S. isolate of bluetongue virus serotype 11 . Virus Res. 21, 155-162.

Eaton, B. T., and Crameri, G. S. (1989). The site of bluetongue virus attachment to glycophorins from a number of animal erythrocytes. J. Gen. Virol. 70, 3347-3353.

Eaton, B. T., Gould, A. R., Hyatt, A. D., Coupar, B.E., Martyn, J.C., and White, J. R. (1991). A bluetongue serogroupreactive epitope in the amino terminal half of the major core protein VP7 is accessible on the surface of bluetongue virus particles. Virology 180, 687-696.

Eaton, B. T., Hyatt, A. D., and Brookes, S. M. (1990). The replication of bluetongue virus. Curr. Top. Microbiol. Immunol. 162, 89-118.

Eaton, B. T., Hyatt, A. D., and White, J. R. (1987). Association of bluetongue virus with the cytoskeleton. Virology 157, 107-116.

Eaton, B. T., Hyatt, A. D., and White, J. R. (1988). Localization of the nonstructural protein NS2 in bluetongue virus-infected cells and its presence in virus particles. Virology 163, 527-537.

Erasmus, B. J. (1985). The history of bluetongue. Prog. Clin. Biol. Res. 178, 7-12.

Fillmore, G. C., Lin, H., and Li, J. K.-K. (2002). Localization of the singlestranded RNA-binding domains of bluetongue virus nonstructural protein NS2. J. Virol. 76, 499-506.

French, T. J., Marshall, J. J., and Roy, P. (1990). Assembly of double-shelled, virus like particles of bluetongue virus by the simultaneous expression of four structural proteins. J. Virol. 64, 5695-5700.

French, T. J., and Roy, P. (1990). Synthesis of bluetongue virus (BTV) core-like particles by a recombinant baculovirus expressing the two major structural core proteins of BTV. J. Virol. 64, 1530-1536.

Fukusho, A., Ritter, G. D., and Roy, P. (1987). Variation in the bluetongue virus neutralization protein VP2. J. Gen. Virol. 68, 2967-2973.

Fukusho, A., Yu, Y., Yamaguchi, S., and Roy, P. (1989). Completion of the sequence of bluetongue virus serotype 10 by the characterization of a structural protein, VP6, and a nonstructural protein, NS2. J. Gen. Virol. 70, 1677-1689.

Geysen, H. M. (1990). Molecular technology: peptide epitope mapping and the pin technology. Southeast Asian J. Trop. Med. Public Health 21, 523-533.

Geysen, H. M., Barteling, S. J., and Meloen, R. H. (1985). Small peptides induce antibodies with a sequence and structural requirement for binding antigen comparable to antibodies raised against the native protein. Proc. Natl. Acad. Sci. U.S.A. 82, 178-182.
Ghiasi, H., Purdy, M. A., and Roy, P. (1985). The complete sequence of bluetongue virus serotype 10 segment 3 and its predicted VP3 polypeptide compared with those of BTV serotype 17. Virus Res. 3, 181-190.

Gibbs, E. P. (1983). Bluetongue--an analysis of current problems, with particular reference to importation of ruminants to the United States. J. Am. Vet. Med. Assoc. 182, 1190-1194.

Gibbs, E.P. J., Greiner,E.C., and Alexander, F. C. M. (1983). Serological survey of ruminant livestock in some countries of the Caribbean region and South America for antibody to bluetongue virus. Vet. Rec. 113, 446-448.

Goltz, J. (1978). Bluetongue in cattle: a review. Can. Vet. J. 19, 95-98.

Gorman, B. M. (1990). The bluetongue viruses. Curr. Top. Microbiol. Immunol. $162,1-19$.

Gouet, P., Diprose, J. M., Grimes, J. M., Malby, R., Burroughs, J. N., Zientara, S., Stuart, D. I., and Mertens, P. P. (1999). The highly ordered doublestranded RNA genome of bluetongue virus revealed by crystallography. $\mathrm{Cell}$ 97, 481-490.

Gould, A. R., Hyatt, A. D., and Eaton, B. T. (1988a). Morphogenesis of a bluetongue virus variant with an amino acid alteration at a neutralization site in the outer coat protein, VP2. Virology $165,23-32$.

Gould, A. R., Pritchard, L. I., and Tavaria, M. D. (1988b). Nucleotide and deduced amino acid sequences of the non-structural protein, NS1, of Australian and South African bluetongue virus serotype 1. Virus Res. 11, 97-107.

Gould, A. R., Martyn, J.C., and Stevenson, L. (1994). Expression of the non-structural protein NS1 of bluetongue virus in bacteria and yeast: identification of two antigenic sites at the amino terminus. Virus Res. 31, 291-303.

Gould, A. R., and Pritchard, L. I. (1988). The complete nucleotide sequence of the outer coat protein, VP5, of the Australian bluetongue virus (BTV) serotype 1 reveals conserved and non-conserved sequences. Virus Res. 9, 285-292.

Grieder, F. B., and Schultz, K. T. (1989). Conformationally dependent epitopes of bluetongue virus neutralizing antigen. Viral Immunol. 2, 17-24.

Grubman, M. J., and Samal, S. (1989). Nucleotide and deduced amino acid sequence of the nonstructural protein NS1, of the US bluetongue virus serotype 17. Nucleic Acids Res. 17, 10498.

Grubman, M. J., Zellner, M., and Samal, S. (1990). Nucleotide and deduced amino acid sequence of the nonstructural phosphoprotein, NS2, of bluetongue virus serotype 17: comparison to two isolates of serotype 10. Virus Res. 15, 243-250.

Guirakhoo, F., Catalan, J.A., and Monath, T.P. (1995). Adaptation of bluetongue virus in mosquito cells results in overexpression of NS3 proteins and release of virus particles. Arch. Virol. 140, 967-974.

Hall, S. J., van Dijk, A. A., and Huismans, H. (1989). Complete nucleotide sequence of gene segment 8 encoding non-structural protein NS2 of SA bluetongue virus serotype 10 . Nucleic Acids Res. 17, 457.

Han, Z. Y., and Harty, R. N. (2004). The NS3 protein of Bluetongue virus exhibits viroporin-like properties. $J$. Biol. Chem. 279, 43092-43097.

Harding, M. J., Prud'homme, I., and Rola, J. (1995). Identification of the major North American bluetongue viruses using nucleic acid amplification techniques. Mol. Cell. Probes 9, 223-231.

Hassan, S. S., and Roy, P. (1999). Expression and functional characterization of bluetongue virus VP2 protein: role in cell entry. J. Virol. 73 , 9832-9842.

Hausler, T. (2006). Viruses vs. Superbugs: A Solution to the Antibiotics Crisis? New York, NY: Macmillan, 1-292.

Hayama, E., and Li, J. K.-K. (1994). Mapping and characterization of antigenic epitopes and the nucleic acid binding domains of the VP6 proteins of bluetongue viruses. J. Virol. 68, 3604-3611.

He, X. S., Wang, L. F., Doi, R. H., Maia, M., Osburn, B. I., and Chuang, R. Y. (1991). Expression of a full-length nonstructural protein NS1 of bluetongue virus serotype 17 in Escherichia coli. Biochem. Biophys. Res. Commun. 180, 994-1001.

Hewat, E. A., Booth, T. F., Loudon, P. T., and Roy, P. (1992a). Threedimensional reconstruction of baculovirus expressed bluetongue virus core-like particles by cryo-electron microscopy. Virology 189, 10-20.

Hewat, E. A., Booth, T. F., and Roy, P. (1992b). Structure of bluetongue virus particles by cryoelectron microscopy. J. Struct. Biol. 109, 61-69.

Hewat, E. A., Booth, T. F., Wade, R. H., and Roy, P. (1992c).3-D reconstruction of bluetongue virus tubules using cryoelectron microscopy. J. Struct. Biol. 108, 35-48.

Hewat, E. A., Booth, T. F., and Roy, P. (1994). Structure of correctly selfassembled bluetongue virus-like particles. J. Struct. Biol. 112, 183-191.

Hill, R., and Lee, P. W. (2010). The DNAdependent protein kinase (DNA-PK): more than just a case of making ends meet? Cell Cycle 9, 3460-3469. 
Hirasawa, T., and Roy, P. (1990). The complete nucleotide sequence of VP5 of a strain of bluetongue virus of serotype 2 isolated in the USA reveals its close relationship with a virus of serotype 1 isolated in Australia. Virus Res. 15, 107-112.

Holtz, A. (2007). To build a killing machine. Scientist 21, 49-55.

Horscroft, N. J., and Roy, P. (2000). NTP binding and phosphohydrolase activity associated with purified bluetongue virus non-structural protein NS2. J. Gen. Virol. 81, 1961-1965.

Hu, J., Dong, C. Y., Li, J. K.-K., Chen, J., Chen, D. E., and Liang, K. (2008). Selective in vitro cytotoxic effect of human cancer cells by bluetongue virus 10. Acta Oncol. 48, 124-134.

Huang, I.-J., Hayama, E., Jeong, Y.-J., and Li, J. K.-K. (1993). Conservation of the segment 4 gene sequence and of a leucine zipper motif in VP4 among five US bluetongue viruses. Virology 195, 772-779.

Huang, I.-J., Hwang, G.-Y., Yang, Y.-Y., Hayama, E., and Li, J. K.-K. (1995). Sequence analyses and antigenic epitope mapping of the putative RNA-dependent RNA polymerase of five U.S. bluetongue viruses. Virology 214, 280-288.

Huang, I. J., and Li, J. K.-K. (1997). Purification of the putative guanylyltransferase of bluetongue virus from both eukaryotic and prokaryotic expression system. Int. J. BioChromatogr. 3, 143-154.

Huang, I. J., and Li, J. K.-K. (2000). Bluetongue viruses and bluetongue diseases. Taiwan Sugar Res. Ins. Bull. $46,8-13$.

Huismans, H. (1979). Protein synthesis in bluetongue virus-infected cells. Virology 92, 385-396.

Huismans, H. (1985). The use of recombinant DNA technology for the development of a bluetongue virus subunit vaccine. Onderstepoort J. Vet. Res. 52, 149-151.

Huismans, H., and Els, H. J. (1979). Characterization of the tubules associated with the replication of three different orbiviruses. Virology 92, 397-406.

Huismans, H., van der Walt, N. T., Cloete, M., and Erasmus, B. J. (1987a). Isolation of a capsid protein of bluetongue virus that induces a protective immune response in sheep. Virology 157, 172-179.

Huismans, H., van Dijk, A. A., and Bauskin, A. R. (1987b). In vitro phosphorylation and purification of a nonstructural protein of bluetongue virus with affinity for the single-stranded RNA. J. Virol. 61, 3589-3595.
Huismans, H., van Dijk, A. A., and Els, H. J. (1987c). Uncoating of parental bluetongue virus to core and subcore particles in infected L cells. Virology 157, 180-188.

Huismans, H., and Van Dijk, A. A. (1990). Bluetongue virus structural components. Curr. Top. Microbiol. Immunol. $162,21-41$.

Hwang, G. Y., Chiou, J. F., Yang, Y. Y., and Li, J. K.-K. (1993). High-sequence conservation among the United States bluetongue viruses cognate $\mathrm{M} 2$ genes which encode the nonstructural NS1 tubule protein. Virology 192,321-327.

Hwang, G.-Y., and Li, J. K.-K. (1993). Identification and localization of antigenic epitopes and an immunodominant serotypic neutralization determinant on the VP2 protein of bluetongue virus 13. Virology 195, 859-862.

Hwang, G.-Y., Xiang, M., and Li, J. K.-K. (1994). Analyses and conservation of sequence among the cognate L3 segments of five bluetongue viruses. Virus Res. 32, 381-389.

Hwang, G.-Y., Yang, Y.-Y., Chiou, J.-F., and Li, J. K.-K. (1992a). Sequence conservation among the cognate nonstructural NS3/3A protein genes of six bluetongue viruses. Virus Res. 23, 151-161.

Hwang, G.-Y., Chiou, J.-F., Yang, Y.-Y., and Li, J. K.-K. (1992b). Comparative sequence analyses of the cognate structural protein VP6 genes of five US bluetongue viruses. Virus Res. 24, 315-323.

Hyatt, A. D., Eaton, B. T., and Brookes, S. M. (1998). The release of bluetongue virus from infected cells and their superinfection by progeny virus. Virology 173, 21-34.

Hyatt, A. D., Gould, A. R., Coupar, B., and Eaton, B. T. (1991). Localization of the non-structural protein NS3 in bluetongue virus-infected cells. J. Gen. Virol. 72, 2263-2267.

Hyatt, A. D., Zhao, Y., and Roy, P. (1993), Release of bluetongue virus-like particles from insect cells is mediated by BTV non-structural NS3/NS3A. Virology 193, 592-603.

Iwata, H., Hirasawa, T., and Roy, P. (1991). Complete nucleotide sequence of segment 5 of epizootic haemorrhagic disease virus; the outer capsid protein VP5 is homologous to the VP5 protein of bluetongue virus. Virus Res. 20, 273-281.

Jameson, P., and Grossberg, S. E. (1981). Preparation and characterization of bluetongue virus. Meth. Enzymol. 78, 312-315.

Jeggo, M. H., Gumm, I. D., and Taylor, W. P. (1983). Clinical and serological response of sheep to serial challenge with different bluetongue virus types. Res. Vet. Sci. 34, 205-211.

Jeggo, M. H., and Wardley, R. C. (1982a). Generation of cross-reactive cytotoxic T-lymphocytes following immunization of mice with various bluetongue virus types. Immunology $45,629-635$.

Jeggo, M. H., and Wardley, R. C. (1982b). The induction of murine cytotoxic T-lymphocytes by bluetongue virus. Arch. Virol. 71, 197-206.

Jeggo, M. H., and Wardley, R. C. (1985) Bluetongue vaccine: cells and/or antibodies. Vaccine 3, 57-58.

Jones, L. D., Chuma, T., Hails, R., Williams, T., and Roy, P. (1996). The nonstructural proteins of bluetongue virus are a dominant source of cytotoxic $\mathrm{T}$ cell peptide determinants. J. Gen. Virol 77, 997-1003.

Jones, L. D., Williams, T., Bishop, D., and Roy, P. (1997). Baculovirus-expressed nonstructural protein NS2 of bluetongue virus induces a cytotoxic T-cel response in mice which affords partial protection. Clin. Diagn. Lab. Immunol. 4, 297-301.

Kikuchi,H.,Ujiie, S., Wakui,A., Yokoyama, A., and Kanamaru, R. (1997). Features of DNA oligonucleosomal fragmentation in human tumor cell lines and its detection by flow cytometry: utility and limitation. Jpn. J. Cancer Res. $88,56-65$.

Kim, J. H., Oh, J. Y., Park, B. H., Lee, D. E. Kim, J. S., Park, H. E., Roh, M. S., Je, J. E., Yoon, J. H., Thorne, S. H., Kirn, D., and Hwang, T.H. (2006). Systemic armed oncolytic and immunologic therapy for cancer with JX-594, a targeted poxvirus expressing GM-CSF Mol. Ther. 14, 361-370.

Kim, M., Egan, C., Alain, T., Urbanski, S. J., Lee, P. W., Forsyth, P. A., and Johnston, R. N. (2007). Acquired resistance to reoviral oncolysis in Ras-transformed fibrosarcoma cells. Oncogene 26, 4124-4134.

King, B. M., and Alders, M. A. (1985) Morphology of bluetongue virusinfected Aedes albopictus (C6/36) cell culture. Prog. Clin. Biol. Res. 178 289-294.

Kowalik, T. F., and Li, J. K.-K. (1987) The genetic relatedness of United States prototype bluetongue viruses by RNA/RNA hybridization. Virology 158, 276-284.

Kowalik, T. F., and Li, J. K.-K. (1989). Sequence analysis and structural predictions of double-stranded RNA segments S1 and VP7 from United States prototype bluetongue virus serotype 13 and 10. Virology 172, 189-195.

Kowalik, T. F., and Li, J. K.-K. (1991). Bluetongue virus evolution: sequence analysis of five genome segment $\mathrm{S} 1$ and major core protein VP7. Virology 181, 749-755.

Kowalik, T. F., Li, J. K.-K., Chuang, R., Osburn, B., and Doi, R. (1990a). The complete nucleotide and deduced amino acid sequence of the gene encoding the major inner capsid protein, VP7, of U.S. prototype bluetongue virus serotype 17. Nucleic Acids Res. 18, 5302.

Kowalik, T. F., Yang, Y.-Y., and Li, J. K.-K. (1990b). Molecular cloning and comparative sequence analyses of bluetongue virus $\mathrm{S} 1$ segments by selective synthesis of specific fulllength DNA copies of ds-RNA genes. Virology 177, 820-823.

Lam, J. T., Hemminki, A., Kanerva, A., Lee, K. B., Blackwell, J. L., Desmond, R., Siegal, G. P., and Curiel, D. T. (2007). A three-dimensional assay for measurement of viral-induced oncolysis. Cancer Gene Ther. 14, 421-430.

LeBlois, H., French, T., Mertens, P. P. C. Burroughs, J. N., and Roy, P. (1992). The expressed VP4 protein of bluetongue virus binds GTP and is the candidate guanylyltransferase of the virus. Virology 189, 757-761.

Lee, J., and Roy, P. (1987). Complete sequence of the NS1 gene (M6 RNA) of US bluetongue virus serotype 10 . Nucleic Acids Res. 15, 7207.

Lee, J. W., and Roy, P. (1986). Nucleotide sequence of a cDNA clone of RNA segment 10 of bluetongue virus (serotype 10). J. Gen. Virol. 67, 2833-2837.

Lei, S. L., Xiao, A. T., Liu, C. X., Chen, B. P., Fang, P., and Dong, C. Y. (2004). Comparison of Infectivity of BTV$\mathrm{HbC} 3$ to SPC-A-1 with That of BTV10 Prototype. Med. J. Wuhan Univ. 25 669-671.

Lewis, S. A., and Grubman, M. J. (1990). Bluetongue virus: surface exposure of VP7. Virus Res. 16, 17-26.

Li, J. K.-K., Kowalik, T., and Parker, B. (1987). Rapid alkaline blottransfer of viral ds-RNA. Anal. Biochem. 163 , 210-218.

Li, J. K.-K., and Hwang, G.-Y. (1992). "Identification of a serotypic neutralization epitope unique to VP2 of bluetongue virus 13," in Bluetongue, African Horse Sickness and Related Orbiviruses, eds T. E. Walton and B. I. Osburn (Boca Raton, FL: CRC Press), 439-443.

Li, J. K.-K., and Yang, Y.-Y. (1990). Mapping of two immuno-dominant antigenic epitopes conserved among the major inner capsid protein, VP7 of five bluetongue viruses. Virology $178,552-559$.

Li, J. K.-K., and Yang, Y.-Y. (1992). "Biochemical and immunological characterization of VP5 of five US bluetongue viruses," in Bluetongue, 
African Horse Sickness and Related Orbiviruses, eds T. E. Walton and B. I. Osburn (Boca Raton, FL: CRC Press), 433-438.

Li, J. K-K., Johnson, T., Yang, Y. Y., and Shore, V. (1989). Selective separation of virus proteins and double-stranded RNAs by SDS-KCl precipitation. J. Virol. Methods 26, 3-15.

Liang, K., Dong, C. Y., Zhang, W. Y., Hu, J., and Chen, J. (2006). The infectivity of bluetongue virus strain $\mathrm{HbC} 3$ to MA782 cell. Virol. Sin. 21, 168-171.

Limn, C. K., Staeuber, N., Monastyrskaya, K., Gouet, P., and Roy, P. (2000). Functional dissection of the major structural protein of bluetongue virus: identification of key residues within VP7 essential for capsid assembly. J. Virol. 74, 8658-8669.

Lin, M., and Zhou, E.M. (1996). Biological mimicry of the bluetongue virus core protein VP7 by rabbit anti-idiotype. Microbiol. Immunol. 40, 435-441.

Liu, H.M., Booth, T. F., and Roy, P. (1992). Interactions between bluetongue virus core and capsid proteins translated in vitro. J. Gen. Virol. 73, 2577-2584.

Liu, T.-C., Glanais, E., and Kirn, D. (2007). Clinical trial results with oncolytic virotherapy: a century of promise, a decade of progress. Nat. Clin. Pract. Oncol. 4, 101-117.

Liu, X.Y. (2006). Targeting gene-virotherapy of cancer and its prosperity. Cell Res. 16, 879-886.

Loudon, P. T., and Roy, P. (1991). Assembly of five bluetongue virus proteins expressed by recombinant baculoviruses: inclusion of the largest protein VP1 in the core and virus-like proteins. Virology 180, 798-802.

Marcato, P., Shmulevitz, M., Pan, D., Stoltz, D., and Lee, P. W. K. (2007). Ras transformation mediates reovirus oncolysis by enhancing virus uncoating, particle infectivity, and apoptosis-dependent release. $\mathrm{Mol}$. Ther. 15, 1522-1530.

Marshall, J. J., Fayard, B., and Roy, P. (1990). Biophysical studies on the morphology of baculovirus-expressed bluetongue virus tubules. J. Gen. Virol. 71, 1839-1844.

Marshall, J. J., and Roy, P. (1990). High level expression of the two outer capsid proteins of bluetongue virus serotype 10: their relationship with the neutralization of virus infection. Virus Res. 15, 189-195.

Martinez-Costas, J., Sutton, G., Ramadevi, N., and Roy, P. (1998). Guanylylytransferase and RNA 5'-triphosphatase activities of the purified expressed VP4 protein of bluetongue virus. J. Mol. Biol. 280, 859-866.

Martyn, J. C., Gould, A. R., and Eaton, B. T. (1991). High level expression of the major core protein VP7 and the nonstructural protein NS3 of bluetongue virus in yeast: use of expressed VP7 as a diagnostic, group-reactive antigen in a blocking ELISA. Virus Res. 18, 165-178.

Martyn, J. C., Gould, A. R., and Yu, M. (1994). Expression of the outer capsid proteins VP2 and VP5 of bluetongue virus in Saccharomyces cerevisiae. Virus Res. 33, 11-25.

Mecham, J. O., and Jochim, M. M. (1990). Monoclonal antibodies to bluetongue virus define two neutralizing epitopes and a hemagglutinating epitope. Viral Immunol. 3, 161-170.

Medzhitov, R., and Janeway, C. (2002). Innate immune recognition. Annu. Rev. Immunol. 20, 197-216.

Mertens, P. P., Brown, F., and Sangar, D. V. (1984). Assignment of the genome segments of bluetongue virus type 1 to the proteins which they encode. Virology 135, 207-217.

Mertens, P. P., Burroughs, J. N., and Anderson, J. (1987). Purification and properties of virus particles, infectious subviral particles, and cores of bluetongue virus serotypes 1 and 4 . Virology 157, 375-386.

Mertens, P. P., Burroughs, J. N., Walton, A., Wellby, M. P., Fu, H., O'Hara, R. S., Brookes, S. M., and Mellor, P.S. (1996). Enhanced infectivity of modified bluetongue virus particles for two insect cell lines and for two Culicoides vector species. Virology 217, 582-593.

Mertens, P. P., and Sangar, D. V. (1985). Analysis of the terminal sequences of the genome segments of four orbiviruses. Prog. Clin. Biol. Res. 178, 371-387.

Mikhailov, M., Monastyrskaya, K., Bakker, T., and Roy, P. (1996). A new form of particulate single and multiple immunogen delivery system based on recombinant bluetongue virus-derived tubules. Virology 217, 323-331.

Monastyrskaya, K., Booth, T., Nel, L., and Roy, P. (1994). Mutation of either of two cysteine residues or deletion of the amino or carboxy terminus of nonstructural protein NS1 of bluetongue virus abrogates virus-specified tubule formation in insect cells. J. Virol. 68, 2169-2178.

Mortola, E., Noad, R., and Roy, P. (2004). Bluetongue virus outer capsid proteins are sufficient to trigger apoptosis in mammalian cells. J. Virol. 78, 2875-2883.

Moss, S. R., Fukusho, A., and Nuttall, P. A. (1990). RNA segment 5 of broadhaven virus, a tick-borne orbivirus, shows sequence homology with segment 5 of bluetongue virus. Virology $179,482-484$.
Mullens, B. A., Tabachnick, W. J., Holbrook, F. R., and Thompson, L. H. (1995). Effects of temperature on virogenesis of bluetongue virus serotype 11 in Culicoides variipennissonorensis. Med. Vet. Entomol. 9, 71-76.

Murray, P. K., and Eaton, B. T. (1996). Vaccines for bluetongue. Aust. Vet. J. $73,207-210$.

Nagesha, H. S., Wang, L. F., Shiell, B., Beddome, G., White, J. R., and Irving, R. A. (2001). A single chain Fv antibody displayed on phage surface recognizes conformational groupspecific epitope of bluetongue virus. J. Virol. Methods 91, 203-207.

Nel, L. H., Picard, L. A., and Huismans, H. (1991). A characterization of the nonstructural protein from which the virus-specified tubules in epizootic haemorrhagic disease virus-infected cells are composed. Virus Res. 18, 219-230.

Norman, K. L., Kirasawa, K., Yang, A. D., Shields, M. A., and Lee, P. W. K. (2004). Reovirus oncolysis: the Ras/ RalGEF/p38 pathway dictates host cell permissiveness to reovirus infection. Proc. Natl. Acad. Sci. U.S.A. 101 , 11099-11104.

Norman, K. L., and Lee, P. W. K. (2005) Not all viruses are bad guys: the case for reovirus in cancer therapy. Drug Discov. Today 10, 847-855.

Oberst, R. D., Stott, J. L., BlanchardChannell, M., and Osburn, B. I. (1987). Genetic reassortment of bluetongue virus serotype 11 strains in the bovine. Vet. Microbiol. 15, 11-18.

Odeon, A. C., Gershwin, L. J., and Osburn, B. I. (1999). IgE responses to bluetongue virus (BTV) serotype 11 after immunization with inactivated BTV and challenge infection. Comp Immunol. Microbiol. Infect. Dis. 22, 145-162.

Oldfield, S., Adachi, A., Urakawa, T., Kirasawa, T., and Roy, P. (1990). Purification and characterization of the major group-specific core antigen VP7 of bluetongue virus synthesized by a recombinant baculovirus. J. Gen. Virol. 71, 2649-2656.

Oldfield, S., Hirasawa, T., and Roy, P. (1991). Sequence conservation of the outer capsid protein, VP5, of bluetongue virus, a contrasting feature to the outer capsid protein VP2. J. Gen. Virol. 72, 449-451.

Osburn, B. I. (1994). Bluetongue virus. Vet. Clin. North Am. Food Anim. Pract. $10,547-560$.

Ou,J.J.-H., and Yen, B. T.S. (2010). Human Oncogenic Viruses. Singapore: World Scientific Publishing Co., 1-339.

Poggioli, G. J., Keefer, J. L., Connolly, T. S., Dermody, T. S., and Tyler, K. L. (2000). Reovirus-induced G2/M cell cycle arrest requires $\sigma 1 \mathrm{~s}$ and occurs in the absence of apoptosis. J. Virol. 74, 9562-9570.

Prasad, G., and Minakshi. (1999). Comparative evaluation of sensitivity of RNA-polyacrylamide gel electrophoresis and dot immunobinding assay for detection of bluetongue virus in cell culture. Indian J. Exp. Biol. 37, 157-160.

Prasad, G., Minakshi, Malik, Y., and Maan, S. (1999). RT-PCR and its detection limit for cell culture grown bluetongue virus 1 using NS1 gene group specific primers. Indian J. Exp. Biol.37, 1255-1258.

Pritchard, L. I., and Gould, A. R. (1995). Phylogenetic comparison of the serotype-specific VP2 protein of bluetongue and related orbiviruses. Virus Res. 39, 207-220.

Pritchard, L. I., Gould, A. R., Wilson, W. C., Thompson, L., Mertens, P. P., and Wade-Evans, A. M. (1995). Complete nucleotide sequence of RNA segment 3 of bluetongue virus serotype 2 (Ona-A). Phylogenetic analyses reveal the probable origin and relationship with other orbiviruses. Virus Res. 35 , 247-261.

Purdy, M., Petre, J., and Roy, P. (1984). Cloning of the bluetongue virus L3 gene. J. Virol. 51, 754-759.

Qi, R., Gu, J., Zhang, Z., Yang, K., Li, B., Fan, J., Wang, C., He, Z., Qiao, L., Lin, Z., and Liu, X. Y. (2007). Potent antitumor efficacy of XAF1 delivered by conditionally replicative adenovirus vector via caspase-independent apoptosis. Cancer Gene Ther. 14, 82-90.

Ramadevi, N., Burroughs, N. J., Mertens, P. P., Jones, I. M., and Roy, P. (1998a). Capping and methylation of mRNA by purified recombinant VP4 protein of bluetongue virus. Proc. Natl. Acad. Sci. U.S.A. 95, 13537-13542.

Ramadevi, N., Rodriguez, J., and Roy, P. (1998b). A leucine zipper-like domain is essential for dimerization and encapsidation of bluetongue virus nucleocapsid protein VP4. J. Virol. 72, 2983-2990.

Ramadevi, N., and Roy, P. (1998). Bluetongue virus core protein VP4 has nucleoside triphosphate phosphohydrolase activity. J. Gen. Virol. 79, 2475-2480.

Ramig, R. F., Garrison, C., Chen, D., and Bell-Robinson, D. (1989). Analysis of reassortment and superinfection during mixed infection of Vero cells with bluetongue virus serotypes 10 and 17 . J. Gen. Virol. 70, 2595-2603.

Ribacka, C., Personen, S., and Hemmink, A. (2008). Cancer, stem cells, and oncolytic viruses. Ann. Med. 40, 49-505. 
Rodgers, S. E., Barton, E. S., Oberhaus, S. M., Pike, B., Gibson, C. A., Tyler, K. L., and Dermody, T. S. (1997). Reovirusinduced apoptosis of MDCK cells is not linked to viral yield and is blocked by Bcl-2. J. Virol. 71, 2540-2546.

Rossitto, P. V., and MacLachlan, N. J. (1992). Neutralization epitopes of the serotypes of bluetongue virus present in the United States. J. Gen. Virol. 73, 1947-1952.

Roth, J. P., Li, J. K.-K., and Dale, B. L. (2010). Human parainfluenza virus type 3 (HPIV-3): construction and rescue of an infectious, recombinant virus expressing the enhanced green fluorescent protein (GFP). Curr. Protoc. Microbiol.17, 15F.1.1-15F.1.22.

Roy, P. (1989). Bluetongue virus genetics and genome structure. Virus Res. 13, 179-206.

Roy, P. (1992). Bluetongue virus proteins. J. Gen. Virol. 73, 3051-3064.

Roy, P. (1996). Orbivirus structure and assembly. Virology 216, 1-11.

Roy, P. (2003). Nature and duration of protective immunity to bluetongue virus infection. Dev. Biol. 114, 169-183.

Roy, P., Adachi, A., Urakawa, T., Booth, T. F., and Thomas, C. P. (1990a). Identification of bluetongue virus VP6 protein as a nucleic acid-binding protein and the localization of VP6 in virus-infected vertebrate cells. J. Virol. $64,1-8$.

Roy, P., Marshall, J. J., and French, T. J. (1990b). Structure of the bluetongue virus genome and its encoded proteins. Curr. Top. Microbiol. Immunol. $162,43-87$.

Roy, P., Urakawa, T., Van Dijk, A. A., and Erasmus, B. J. (1990c). Recombinant virus vaccine for bluetongue disease in sheep. J. Virol. 64, 1998-2003.

Roy, P., Boyce, M., and Noad, R. (2009). Prospects for improved bluetongue vaccines. Nat. Rev. Microbiol. 7, 120-128.

Roy, P., French, T. J., and Erasmus, B. J. (1992). Protection efficacy of viruslike particles for bluetongue disease. Vaccine 10, 28-32.

Roy, P., Fukusho, A., Ritter, G. D., and Lyon, D. (1988). Evidence for genetic relationship between RNA and DNA viruses from the sequence homology of a putative polymerase gene of bluetongue virus with that of vaccinia virus: conservation of RNA polymerase genes from diverse species. Nucleic Acids Res. 16, 11759-11767.

Roy, P., and Gorman, B. M. (eds). (1990). Bluetongue virus. Curr. Top. Microbiol. Immunol. 162, 1-200.

Roy, P., Hirasawa, T., Fernandez, M., Blinov, V. M., and Rodrique, J. M. S.-V. (1991). The complete sequence of the group-specific antigen, VP7, of African horsesickness disease virus serotype 4 reveals a close relationship to bluetongue virus. J. Gen. Virol. 72, 1237-1241.

Roy, P., and Noad, R. (2006). Bluetongue virus assembly and morphogenesis. Curr. Top. Microbiol. Immunol. 309, 87-116.

Samal, S. K., El-Hussein, A., Holbrook, F. R., Beaty, B. J., and Ramig, R. F. (1987). Mixed infection of Culicoides variipennis with bluetongue virus serotypes 10 and 17: evidence for high frequency reassortment in the vector. J. Gen. Virol. 68, 2319-2329.

Samal, S. K., McConnell, S., and Ramig, R. F. (1985). Growth characteristics of virulent and attenuated strains of bluetongue virus serotypes 10, 11, 13 and 17. Prog. Clin. Biol. Res. 178, 407-412.

Schoehn, G., Moss, S. R., Nuttall, P.A., and Hewat, E. A. (1997). Structure of broad haven virus by cryoelectron microscopy: correlation of structural and antigenic properties of broadhaven virus and bluetongue virus outer capsid proteins. Virology 235, 191-200.

Shen, Y., and Nemunaitis, J. (2006). Herpes simplex virus 1 (HSV-1) for cancer treatment. Cancer Gene Ther. 13, 975-992.

Shipham, S. (1979). Further characterization of the t-s mutant F207 of bluetongue virus. Onderstepoort J. Vet. Res. $46,207-210$.

Shmulevitz, M., Marcato, P., and Lee, P. W. K. (2005). Unshackling the links between reovirus oncolysis, Ras signaling, translational control and cancer. Oncogene 24, 7720-7772.

Shmulevitz, M., Pan, L.Z., Garant, K., Pan, D., and Lee, P.W.K. (2010). Oncogenic Ras promotes revovirus spread by suppressing IFN-beta production through negative regulation of RIG-I signaling. Cancer Res. 70, 4912-4921.

Singer, R. A. (1976). "Lysogeny and toxinogenicity in Corynebacterium diphtheriae," in Mechanisms in Bacterial Toxinology, ed. A. W. Bernheimer (New York: John Wiley), 1-30.

Stauber, N., Martinez-Costas, J., Sutton, G., Monastyrskaya, K., and Roy, P. (1997). Bluetongue virus VP6 protein binds ATP and exhibits an RNAdependent ATPase function and a helicase activity that catalyze the unwinding of double-stranded RNA substrates. J. Virol. 71, 7220-7226.

Stott, J. L., Barber, T. L., and Osburn, B. I. (1985). Immunologic response of sheep to inactivated and virulent bluetongue virus. Am. J. Vet. Res. 46 , 1043-1049.

Strong, J. E., Coffey, M. C., Tang, D., Sabinin, D., and Lee, P. W. K. (1998).
The molecular basis of viral oncolysis: usurpation of the Ras signaling pathway by reovirus. $E M B O 17$, 3351-3362.

Sundin, D. R., and Mecham, J. O. (1989). Enhanced infectivity of bluetongue virus in cell culture by centrifugation. J. Clin. Microbiol. 27, 1659-1660.

Tan, B. H., Nason, E., Staeuber, N., Jiang, W., Monastryrskaya, K., and Roy, P. (2001). RGD tripeptide of bluetongue virus VP7 protein is responsible for core attachment to Culicoides cells. J. Virol. 75, 3937-3947.

Tanaka, S., Mikhailov, M., and Roy, P. (1995). Synthesis of bluetongue virus chimeric VP3 molecules and their interactions with VP7 protein to assemble into virus core-like particles. Virology 214, 593-601.

Tanaka, S., and Roy, P. (1994). Identification of domains in bluetongue virus VP3 molecules essential for the assembly of virus cores. J. Virol. 68, 2795-2802.

Taraporewala, Z. F., Chen, D., and Patton, J. T. (2001). Multimers of the bluetongue virus nonstructural protein NS2, possess nucleotidyl phosphatase activity: similarities between NS2 and rotavirus NSP2. Virology 280 221-231.

Theron, J., and Nel, L. H. (1997). Stable protein-RNA interaction involves the terminal domains of bluetongue virus mRNA, but not the terminally conserved sequences. Virology 229, 134-142.

Thirukkumaran, C. M., Nodwell, M. J., Hiasawa, K., Shi,Z. Q., Diaz, R., Luider, J., Johnston, R. N., Forsyth, P. A. Magliocco, A. M., Lee, P., Nishikawa, S., Donnelly, B., Coffee, M., Trpkov, K. Fonseca, K., Spurrell, J., and Morris, D. G. (2010). Oncolytic viral therapy for prostate cancer: efficacy of reovirus as a biological therapeutic. Cancer Res. 70, 2435-2444.

Tiwari, A. K., Kataria, R. S., Desai, G., Butchaiah, G., and Bandyopadhyay, S. K. (2000). Characterization of an Indian bluetongue virus isolate by RT-PCR and restriction enzyme analysis of the VP-7 gene sequence. Vet. Res. Commun. 24, 401-409.

Tsuboi, T., and Imada, T. (1997). Effect of bovine herpes virus-1, bluetongue virus and akabane virus on the in vitro development of bovine embryos. Vet. Microbiol. 57, 135-142.

Uitenweerde, J. M., Theron, J., Stoltz, M. A., and Huismans, H. (1995). The multimeric nonstructural NS2 proteins of bluetongue virus, African horsesickness virus, and epizootic hemorrhagic disease virus differ in their single-stranded RNA-binding ability. Virology 209, 624-632.
Unger, R. E., Chuang, R. Y., Chuang, L. F., Osburn, B. I., and Doi, R. H. (1988). The cloning of full-length genome segments $2,5,6$, and 8 of bluetongue virus (BTV) serotype 17 and studies of their genetic relatedness to United States BTV serotypes. Virology 167, 296-298.

Urakawa, T., and Roy, P. (1988). Bluetongue virus tubules made in insect cells by recombinant baculoviruses: expression of the NS1 gene of bluetongue virus serotype 10. J. Virol. 62, 3919-3927.

Valenzuela, D. M., and Groffen, J. (1986). Four human carcinoma cell lines with novel mutations in position 12 of c-K-ras oncogene. Nucleic Acids Res. $14,843-852$.

Van Dijk, A. A. (1993). Development of recombinant vaccines against bluetongue. Biotechnol. Adv. 11, 1-12.

Van Diik, A. A., and Huismans, H. (1982). The effect of temperature on the in vitro transcriptase reaction of bluetongue virus, epizootic haemorrhagic disease virus and African horsesickness virus. Onderstepoort J. Vet. Res. 49, 227-232.

Van Dijk, A. A., and Huismans, H. (1988). In vitro transcription and translation of bluetongue virus mRNA. J. Gen. Virol. 69, 573-581.

Vidal, L., Yap, T. A., White, C. L., Twigger, K., Hingorani, M., Agrawal, V., Kaye, S. B., Harrington, K. J., and de Bono, J. S. (2006). Reovirus and other oncolytic viruses for the targeted treatment of cancer. Target Oncol. 1, 130-150.

Vorburger, S. A., Pataer, A., Swisher, S. G., and and. Hunt, K. K. (2004). Genetically targeted cancer therapy: tumor destruction by PKR activation. Am. J. Pharmacogenomics 4, 189-198.

Wade-Evans, A. M. (1990a). Complete sequence of genome segment 10 , encoding the NS3 protein, of bluetongue virus, serotype 1 from South Africa. Nucleic Acids Res. 18, 4920.

Wade-Evans, A.M. (1990b). The complete nucleotide sequence of genome segment 7 of bluetongue virus, serotype 1 from South Africa. Nucleic Acids Res. $18,4919$.

Wade-Evans, A. M. (1992). The complete sequence of genome segment 8 of bluetongue virus, serotype 1 , which encodes the nonstructural protein NS2. Gene 118, 295-296.

Wade-Evans, A. M., Mertens, P. P., and Belsham, G. J. (1992). Sequence of genome segment 9 of bluetongue virus (serotype 1, South Africa) and expression analysis demonstrating that different forms of VP6 are derived from initiation of protein synthesis at two distinct sites. J. Gen. Virol. 73 , 3023-3026 
Wade-Evans, A. M., Romero, C. H., Mellor, P., Takamatsu, H., Anderson, J., Thevasagayam, J. Fleming, M. J., Mertens, P. P. C., and Black, D. N. (1996). Expression of the major structural protein (VP7) of bluetongue virus, by a recombinant capripox virus, provides partial protection of sheep against a virulent heterotypic bluetongue virus challenge. Virology 220, 227-231.

Waldvogel, A. S., Anderson, C. A., Higgins, R. J., and Osburn, B. I. (1987). Neurovirulence of the UC- 2 and UC- 8 strains of bluetongue virus serotype 11 in newborn mice. Vet. Pathol. 24, 404-410.

Wang, C. S., Lueker, D. C., and Chow, T. L. (1972). Soluble antigen of bluetongue virus. Infect. Immun. 5, 467-473.

Wang, L., Kemp, M. C., Roy, P., and Collisson, E. W. (1988). Tissue tropism and target cells of bluetongue virus in the chicken embryo. J. Virol. 62, 887-893.

Wang, L. F., Doi, R. H., Osburn, B. I., and Chuang, R. Y. (1989). Complete sequence of the NS1 gene (S6 RNA) of US bluetongue virus serotype 17 . Nucleic Acids Res. 17, 8002.

Wang, L. F., Hyatt, A. D., Whiteley, P. L., Andrew, M., Li, J. K.-K., and Eaton, B. T. (1996). Topography and immunogenicity of bluetongue virus VP7 epitopes. Arch. Virol. 141, 111-123.

Wang, L. F., Scanlon, D. B., Kattenbelt, J.A., Mecham, J. O., and Eaton, B. T. (1994). Fine mapping of a surface-accessible, immunodominant site on the bluetongue virus major core protein VP7. Virology 204, 811-814.

Wechsler, S. J., and McHolland, L. E. (1998). Susceptibilities of 14 cell lines to bluetongue virus infection. J. Clin. Microbiol. 26, 2324-2327.

Whetter, L. E., Gebhard, D. H., and MacLachlan, N. J. (1990). Temporal appearance of structural and nonstructural bluetongue viral proteins in infected cells, as determined by immunofluorescence staining and flow cytometry. Am. J. Vet. Res. 51, 1174-1179.

Wildner, O. (2003). Comparison of replication-selective, oncolytic viruses for the treatment of human cancers. Curr. Opin. Mol. Ther. 5, 351-361.

Wilson, W. C. (1991). Molecular comparison of VP3 from bluetongue and epizootic hemorrhagic disease viruses. Virus Res. 21, 225-236.

Wu, X., Chen, S. Y., Iwata, H., Compans, R. W., and Roy, P. (1992). Multiple glycoproteins synthesized by the smallest RNA segment (S10) of bluetongue virus. J. Virol. 66, 7104-7112.

Xiao, A. T., Dong, C. Y., Li, J. K.-K., Chen, D. E., and Liu, J., and Zhang, W. Y. (2004). Studies on the infectivity of bluetongue virus strain $\mathrm{HbC} 3$ to several human and animal tumor cells. Virol. Sin. 19, 349-352.

Xu, G., Wilson, W., Mecham, J., Murphy, K., Zhou, E. M., and Tabachnick, W. (1997).VP7: an attachment protein of bluetongue virus for cellular receptors in Culicoides variipennis. J. Gen. Virol. 78, 1617-1623.

Xue, Q. S. (2001). Principles and Techniques of Culture in vitro. Beijing: Beijing Science Publishing House.

Yang, D. (2009). RNA Viruses: Host Gene Responses to Infection. Singapore: World Scientific Publishing Co., 1-691.

Yang, Y.-Y., Johnson, T. M., Mecham, J. O., Tam, J. P., and Li, J. K.-K. (1992a). Epitopic mapping of the immunodominant linear and conformationdependent antigenic determinants on the major outer capsid protein, GP5, of five US bluetongue viruses. Virology 188, 530-536.

Yang, Y.-Y., Chiou, J. F., Hwang, G. Y. Huang, I.-J., and Li, J. K.-K. (1992b). Evolutionary analyses of five US bluetongue viruses using the cognate S2 genes. Virus Res. 25, 241-249.

Yang, Y.-Y., and Li, J. K.-K. (1992) Complete genomic sequences of the GP5 protein gene of bluetongue virus serotype 11 and 17. Virus Res. 23, 163-171.

Yang, Y.-Y., and Li, J. K.-K. (1993). Glycosylation of the major outer capsid protein of bluetongue virus. Virology 194, 350-354.

Yi, C. K., Bansal, O. B., Hong, M. L., Chatterjee, S., and Roy, P. (1996). Sequences within the VP6 molecule of bluetongue virus that determine cytoplasmic and nuclear targeting of the protein. J. Virol. 70, 4778-4782.

Yu, Y., Fukusho, A., Ritter, D. G., and Roy, P. (1988). Complete nucleotide sequence of the group-reactive antigen VP7 gene of bluetongue virus. Nucleic Acids Res. 16, 1620.

Yu, Y. D., Fukusho, A., and Roy, P. (1987) Nucleotide sequence of the VP4 core protein gene (M4 RNA) of US bluetongue virus serotype 10. Nucleic Acids Res. 15, 7206.

Zhao, Y., Thomas, C., Bremer, C., and Roy, P. (1994). Deletion and mutational analyses of bluetongue virus NS2 protein indicate that the amino but not the carboxyl terminus of the protein is critical for RNA-protein interactions. J. Virol. 68, 2179-2185.

Conflict of Interest Statement: The author declares that the research was conducted in the absence of any commercial or financial relationships that could be construed as a potential conflict of interest.

Received: 10 December 2010; accepted: 01 March 2011; published online: 16 March 2011.

Citation: Li JK-K (2011) Oncolytic bluetongue viruses: promise, progress, and perspectives. Front. Microbio. 2:46. doi 10.3389/fmicb.2011.00046

This article was submitted to Frontiers in Virology, a specialty of Frontiers in Microbiology.

Copyright (C) 2011 Li. This is an open-access article subject to an exclusivelicense agreement between the authors and Frontiers Media SA, which permits unrestricted use, distribution, and reproduction in any medium, provided the original authors and source are credited. 